\title{
Strategi Pengembangan LKMS-BMT Maslahah Sidogiri Pasuruan (Studi Analisis Pendekatan Interpretatif Struktural Modeling) (Strategy of LKMS-BMT Development Maslahah Sidogiri Pasuruan (Analysis Study of Structural Modeling Interpretative Approach))
}

\author{
Parmujianto Parmujianto* \\ STAl Al-Yasini, Pasuruan, Indonesia
}

BMT Maslahah (BMTM) Sidogiri Pasuruan is one of the LKMS that provides Sharia-based financial services. BMTM has not made specific identifications related to the behavior of the target audience which could potentially be a challenge in the future. This study uses a qualitative approach, namely descriptive analysis and Interpretative Structural Modeling (ISM). The results showed that consumer behavior in BMTM is positive in the utilization of BMTM products. Understanding and positive attitude towards BMTM products is based on the motives of daily necessities and business development. The efforts of BMT Maslahah Sidogiri Pasuruan in building consumer loyalty to BMT by bringing services closer to the community, increasing the ratio of supervisors and discipline of supervision and developing several products according to community needs, as well as strengthening human resources.

${ }^{*}$ Correspondence:

Parmujianto Parmujianto parmujianto.008@gmail.com

Received: 21 February 2020 Accepted: 21 March 2020

Published: 30 April 2020

Citation:

Parmujianto $P$ (2020) Strategi

Pengembangan LKMS-BMT

Maslahah Sidogiri Pasuruan (Studi

Analisis Pendekatan Interpretatif

Struktural Modeling) (Strategy of LKMS-BMT Development Maslahah Sidogiri Pasuruan (Analysis Study of Structural Modeling Interpretative

BMT Maslahah (BMTM) Sidogiri Pasuruan adalah salah satu LKMS yang menyelenggarakan jasa keuangan yang berprinsip Syariah. BMTM belum melakukan identfikasi spesifik terkait dengan prilaku khalayak sasaran yang berpotensi dapat menjadi tantangan di masa depan. Penelitian ini menggunakan pendekatan kualitatif, yaitu deskriptif analisis dan Interpretatif Structural Modelling (ISM). Hasil penelitian menunjukkan bahwa perilaku konsumen pada BMTM bersifat positif pada pemanfaatan produk-produk BMTM. Pemahaman dan sikap positif terhadap produk BMTM didasarkan pada motif kebutuhan hidup sehari-hari dan pengembangan usaha. Upaya BMT Maslahah Sidogiri Pasuruan dalam membangun loyalitas konsumen pada BMT dengan mendekatkan layanan kepada masyarakat, meningkatkan rasio dan kedisiplinan pengawasan dan mengembangkan beberapa produk sesuai kebutuhan masyarakat, maupun penguatan SDM.

Kata Kunci: Strategi Pengembangan LKMS BMT 


\section{PENDAHULUAN}

Perkembangan perekonomian yang semakin pesat di Indonesia, juga diikuti oleh semakin sadarnya masyarakat akan pentingnya sarana transaksi keuangan yang tidak hanya didasarkan pada aspek-aspek keamanan transaksi semata akan tetapi juga meliputi nilai-nilai ideologis dalam bertransaksi. Kesadaran tersebut menuntut masyarakat untuk memilih jasa keuangan yang cocok dalam melaksanakan pengambilan keputusan dan atau perilaku dalam proses pengelolaan dana, model akad, maupun perilaku konsumsi dari masyarakat baik perorangan atau organisasi. Perilaku masyarakat dalam menjalankan pengelolaan dana atau transaksi keuangan saat ini dipengaruhi oleh nilai-nilai keagamaan yang diyakini sebagai sumber kebenaran. Dalam Islam, upaya-upaya untuk mengelola dana dan transaksi keuangan secara syariah terus dikembangkan salah satunya dengan keberadaan Lembaga Keuangan Mikro Syariah (LKMS), terutama Baitul maal wa Tamwil (BMT) yang mempraktikkan nilai-nilai keagamaan dengan prinsip-prinsip syariah Ekaningsih (2016)

Aktifitas ekonomi selalu terkait dengan kegiatan produksi, distribusi dan konsumsi. Dalam memahami bagaimana upaya seseorang memenuhi kebutuhannya dengan sumber daya yang dimilikinya, maka perlu dilakukan kajian perilaku konsumen untuk mempelajari bagaimana konsumen berperilaku dan faktor-faktor apa saja yang mempengaruhi perilaku tersebut Kotler (2012).

Perilaku Konsumen pada lingkungan LKMS, terutama pada nasabah BMT juga kompleks dan tidak bisa diprediksi dengan mudah. Sebagaimana halnya perilaku konsumen pada barang, konsumen jasa keuangan juga mengalami perubahan, karena perilaku konsumen dapat dibentuk dan diubah. Perilaku dimulai dari pembentukan sikap, yaitu kecenderungan yang dipelajari dalam berperilaku dengan cara menyenangkan atau tidak menyenangkan terhadap suatu objek. Sikap mempunyai 3 komponen yaitu kognitif (pengetahuan), afektif (sikap) dan konatif (perilaku) konsumen. Posisi perilaku dan sikap bisa berubah ubah sesuai dengan situasi, perilaku dapat mendahului atau mengikuti pembentukan sikap (Schiffman and Kanuk, 2012; Ali, 2002).

Perilaku konsumen juga dipengaruhi oleh agama dan keyakinan penganutnya. Nasabah BMT sebagai komunitas keagamaan yang mendasarkan perilaku hidupnya sesuai dengan norma agama tertentu yang diyakini, dapat sangat dipengaruhi oleh agama. Agama dalam pengertian ini dapat dilihat hanya sebatas persoalan, keyakinan, ketuhanan dan ibadah semata. Keberagamaan (religiusitas) diwujudkan dalam berbagai aspek kehidupan manusia. Padahal agama memberikan pengaruh signifikan terhadap bagaimana konsumen berperilaku. Dalam kadar tertentu dari suatu dimensi tertentu agama yang kompleks ternyata membentuk perilaku ekonomi, walaupun pengaruhnya tidak seragam antar berbagai masyarakat muslim.

Kajian perilaku konsumen dari berbagai kelompok keagamaan sesungguhnya mempunyai nilai penting untuk men- dapatkan gambaran bagi pelaku industri LKMS dalam meningkatkan pangsa pasarnya. Berdirinya LKMS di lingkungan komunitas dan pesantren, seperti BMT Maslahah Sidogiri, menunjukkan telah terjadi penerimaan lembaga keuangan non ribawi.

BMT memiliki peran strategis dalam memacu pertumbuhan perekonomian di Indonesia sehingga dapat mewujudkan struktur perekonomian yang semakin berimbang. Sisi lain fenomena BMT di Indonesia dapat mengantarkan pemahaman masyarakat tentang kelembagaan ekonomi dalam Islam. Kajian tentang ekonomi Islam sebelum munculnya BMT masih dalam bentuk teoritis yang belum implementatif.

Berdirinya BMT sesungguhnya merupakan usaha untuk menerapkan ekonomi syariah secara bertahap dan merupakan ikhtiyar terpadu untuk mengatasi kelemahan umat Islam dalam bidang ekonomi dan kesejahteraan. Keberadaan BMT diharapkan mampu mewujudkan sistem keuangan yang kompetitif, efisien, dan memenuhi prinsip kehati-hatian. Disamping itu keberadaanya diharapkan mampu mendukung sektor riil secara nyata melalui kegiatan pembiayaan berbasis bagi hasil dan transaksi riil dalam mewujudkan keadilan dan saling tolong menolong untuk mencapai kemaslahahatan ekonomi umat.

Kesuksesan lembaga keuangan seperti Bank Muamalat, memicu pertumbuhan Lembaga Keuangan Mikro Syariah (LKMS) non bank seperti Baitul Mal Wa-Tamwil (BMT), pasar modal syariah, reksadana syariah, pegadaian syariah, asuransi syariah, lembaga penjaminan syariah dan lembaga-lembaga ekonomi yang dijalankan dengan prinsip-prinsip syariah. Keberhasilan dan kelanggengan BMT sangat diharapkan oleh umat Islam untuk bisa merealisasikan tujuan-tujuannya. Oleh karena itu, agar BMT dapat bertahan hidup dan berkembang dengan baik, maka ia harus memiliki karakteristik yang sehat sesuai dengan standar yang telah ditetapkan oleh Bank Indonesia.

Di Desa Sidogiri, Kecamatan Krato, Kabupaten Pasuruan telah berdiri LKMS bernama BMT Maslahah (BMTM) Sidogiri pada tanggal 17 Juli 1997, yang semula bernama Koperasi BMT MMU (Maslahahh Mursalah lil Ummah). BMTM Sidogiri telah membuktikan eksistensinya dari tahun ke tahun mengalami perkembangan dan kemajuan yang cukup pesat baik dari jumlah anggota, pegawai dan jumlah kantor pelayanan, maupun kinerja keuangannya.

Akan tetapi, menurut Ali (2002), jika keberhasilannya tidak diimbangi oleh market share, maka industri Lembaga Keuangan Mikro Syariah (LKMS) di Indonesia, akan berdampak pada masalah krusial dalam pengembangan perbankan syariah. Oleh karena itu, market share pada LKMS pada tahun 2008 berbeda dengan tahun-tahun sebelumnya. Pada tahun 2008, Bank Indonesia menargetkan market share $5 \%$ dari total asset perbankan nasional yang merupakan implementasi Cetak Biru Pengembangan Lembaga Keuangan Mikro Syariah (LKMS). Kekhawatiran target pasar 5\% tidak tercapai, maka akan menjadi pemikiran kalangan pemerintah, praktisi, pemerhati, peneliti maupun akademisi keuangan syariah. 
BMT sebagai salah satu lembaga mediasi keuangan di masyarakat harus menjaga kepercayaan nasabah. Tanpa kepercayaan dari nasabah, BMT tidak akan mampu menjalankan kegiatan usahanya dengan baik. Oleh karena itu, penting bagi lembaga ini untuk memegang prinsip amanah sehingga dapat dipercaya oleh nasabah. Kepercayaan timbul melalui proses yang cukup lama sehingga muncul kepuasan dan loyalitas dari nasabah sampai dua belah pihak saling mempercayai. Jika kepercayaan sudah timbul antara BMT dan nasabah, maka usaha untuk membina kerja sama akan lebih mudah. Kondisi ini akan bisa memberi keuntungan bagi dua belah pihak. Dari pihak lembaga, diuntungkan dengan loyalitas nasabah yang sangat berguna bagi kelangsungan hidup lembaga tersebut. Sedangkan bagi nasabah, akan mendapatkan produk yang tepat hingga dapat memuaskan pilihannya.

Oleh karena itu upaya pengembangan BMT tidak cukup hanya berlandaskan kepada aspek-aspek legal dan peraturan perundang-undangan tetapi juga harus berorientasi kepada pasar atau masyarakat sebagai pengguna jasa (nasabah). Hal tersebut akan mempengaruhi persepsi dan sikap masyarakat terhadap BMT. Langkah penting yang harus dilakukan oleh pengelola BMT adalah meningkatkan sosialisasi melalui media massa yang efektif, sehingga pengetahuan masyarakat mengenai BMT tidak hanya terbatas pada produk bagi hasil saja. Harapannya nasabah BMT akan memiliki pengetahuan yang lebih banyak dalam mengambil keputusan tentang berbagai jenis produk yang dikeluarkan oleh BMT. Nasabah akan memiliki informasi yang bijak terkait dengan produk BMT. Menurut Schiffman dan Kanuk perilaku konsumen adalah suatu proses yang dilalui oleh seorang konsumen dalam mencari, membeli, menggunakan, mengevaluasi serta bertindak pada konsumsi barang atau jasa, maupun ide yang diharapkan dapat memenuhi kebutuhan orang tersebut Schiffman and Kanuk (2012). Adapun tindakan tersebut dilakukan melalui terlibat secara langsung dalam proses memperoleh, mengkonsumsi, membuang suatu produk (barang atau jasa).

Pertumbuhan kinerja BMTM Sidogiri cukup tinggi bila dibandingkan produk keuangan syariah lain dari bank-bank konvensional di wilayah Pasuruan. Perbedaan tersebut memunculkan pertanyaan besar bahwa terdapat variasi kinerja antara BMT dengan lembaga keuangan konvensional, yang disebabkan adanya perbedaan perilaku nasabah maupun karakteristik lembaga penyelenggaraan layanan. Oleh karena itu, penelitian ini bertujuan untuk memahami bagaimana perilaku konsumen pada BMT Maslahah Sidogiri Pasuruan dan upayaupaya lembaga dalam membangun loyalitas konsumennya.

\section{METODOLOGI}

Data pada penelitian ini bersifat primer yang dikumpulkan melalui Teknik wawancara pada 111 orang informan konsumen BMT Maslahah dan juga 3 (tiga) orang pakar BMT yaitu, Bapak Dr. Ali Hamdan, MEI, H. Syaifudin Zuhri,MEI dan H. M. Taufik. Sedangkan model penelitian ini menggu- nakan pendekatan kualitatif dengan metode deskriptif analisis digunakan untuk memahami secara mendalam dan menggambarkan kondisi kebutuhan informasi perilaku konsumen pada Baitul Mal Wa tamwil (BMT) Maslahah Sidogiri Pasuruan. Selain itu, penelitian ini juga menggunakan Interpretatif Structural Modelling (ISM) untuk menganalisis kebutuhan rantai pengembangan pada BMT Maslahah Sidogiri Pasuruan. Dasar pengambilan keputusan dalam teknik ISM adalah kelompok. Model struktural dihasilkan guna memotret masalah kompleks dari suatu sistem, melalui pola yang dirancang secara seksama dengan menggunakan grafis serta kalimat. Melalui teknik ISM, model mental yang tidak jelas ditransformasikan menjadi model sistem yang tampak (visible).

Alasan penelitian dengan menggunakan model Interpretatif Structural Modelling adalah suatu model yang mampu menyokong analisis penelitian kualitatif dengan menyajikan hirarki susunan element-elemen yang mampu memotret masalah-masalah yang komplek dari suatu sistem Lembaga Keuangan Mikro Shariah (LKMS)-BMT dengan menggunakan bentuk grafis.

\section{HASIL DAN PEMBAHASAN}

\section{Perilaku Konsumen BMT Maslahah Sidogiri}

Perilaku konsumen BMT Maslahah Sidogiri Pasuruan dapat dipetakan menjadi dua, yaitu perilaku konsumen yang berasal dari Alumni dan non-alumni. Berdirinya BMT Maslahah Sidogiri tidak terlepas dari peran para alumni. Bermula dari keprihatinan para guru Madrasyah Miftahul Ulum yang melihat realita perilaku masyarakat yang cenderung kurang memperhatikan kaidah-kaidah syariah bidang muamalah yang menjalankan praktik-praktik ekonomi yang mengarah pada ribawi yang dilarang oleh agama. Oleh karena itu, alumni Pondok Pesantren Sidogiri mempunyai inisiatif mendirikan koperasi dan kemudian berkembang berdirilah BMT Maslahah Sidogiri.

Perilaku Konsumen yang berasal dari Alumni Pondok Pesantren Sidogiri adalah pada pemahaman dan sikap positif terhadap produk BMT Maslahah didasarkan pada motif kebutuhan hidup sehari-hari dan pengembangan usaha, disamping faktor-faktor penerimaan nilai syariah dalam bentuk keberkahan pada saat menggunakan produk BMT Maslahah. Pengenalan produk BMT Maslahah bersumber dari teman alumni, teman atau kolega kerja, keluarga, dan tetangga selain dari kegiatan pengenalan proaktif dari lembaga. Informasi lanjutan untuk mengkonfirmasi informasi awal pada saat pengenalan produk, dilakukan dengan konfirmasi langsung dengan mendatangi lembaga BMT Maslahah, yang meminimalkan adanya gangguan maupun mispersepsi terhadap layanan jasa keuangan.

Selain alumni, konsumen BMT Maslahah Sidogiri juga berasal dari luar lingkungan pesantren. Perilaku pengguna jasa keuangan BMT Maslahah yang berasal dari non-alumni meliputi pemahaman yang tepat terhadap produk, sikap yang 
positif pada produk yang berasal dari BMT Maslahah, dan kesadaran bertindak dalam bentuk pemilihan dan penggunaan produk BMT Maslahah. Pemahaman dan sikap positif terhadap produk BMT Maslahah didasarkan pada motif kebutuhan hidup sehari-hari dan pengembangan usaha, disamping faktor-faktor penerimaan nilai syariah dalam bentuk keberkahan, akan tetapi motif keimanan bukan menjadi pendorong pemanfaatan produk syariah BMT Maslahah.

Berdasarkan wawancara dengan konsumen dapat diketahui beberapa karakteristik dari konsumen BMT Maslahah. Beberapa latar belakang karakteristik tersebut dapat diketahui dari jenis kelamin, umur, tingkat pendidikan, pekerjaan, maupun kesertaan dalam pembelajaran di pondok pesantren. Secara keseluruhan konsumen dari BMT Maslahah adalah beragama Islam. Heterogennya latar belakang masyarakat membuat pemahaman terhadap agamanya pun beragam. Konsumen dari BMT Maslahah sebagian besar adalah laki-laki, dan sebagian kecilnya adalah perempuan. Umumnya adalah kalangan masyarakat yang sudah berkelurga. Rentang usia dari konsumen adalah berkisar antara 20 sampai 64 tahun. Sebagian besar berada pada kelompok usia produktif yaiitu berusia 3549 tahun.

Tingkat pendidikan konsumen BMT Maslahah adalah bervariasi mulai dari tamatan Sekoleh Dasar sampai perguruan Tinggi. Pendidikan formal ditempuh baik di dalam pondok maupun di luar pondok pesantren. Kelompok masyarakat lulusan SMA dan tamatan SD adalah kelompok terbesar dari konsumen, sedankan sebagian kecilnya adalah tamatan SMP dan perguruan Tinggi. Dari kelompok perguruan tinggi ini konsumen berpendidikan baik mulai Diploma I maupun lulusan Sarjana.

Perkembangan dari BMT Maslahah juga mempengaruhi jumlah yang semakin beragam dari luar pondok pesantren atau alumni santri. Semakin banyak kelompok masyarakat di luar alumni pesantren yang mempercayakan atau memanfaatkan pelayanan BMT Maslahah. Bahkan perkembangan terakhir menunjukkan jumah konsumen BMT Maslahah sebagian besar di dominasi oleh kelompok non alumni. Kondisi ini menunjukkan kepercayaan masyarakat di luar pesantren semakain besar terhadap BMT Maslahah.

Apabila dilihat dari latar belakang pekerjaan atau keprofesian, para konsumen juga sangat beragam. Berbagai latar belakang dari pekerjaan formal maupun informal adalah latar belakang dari para konsumen. Kelompok terbesar dari konsumen BMT Maslahah adalah karyawan prusahaan atau pabrik, kelompok wirausaha, dan Guru. Yang menarik jumlah yang cukup besar juga adalah kelompok yang tidak bekerja dalam hal ini adalah para ibu rumah tangga. Kelompok lainnya adalah berasal dari Petani, Mahasiswa, Pegawai Pemerintah (Perangkat Desa), buruh tani, Buruh Pabrik, serta kelompok yang benar-benar Tidak bekerja (pengangguran). Kondisi ini menunjukkan bahwa BMT Maslahah telah diterima oleh banyak pihak dari latar belakang profesi atau pekerjaan.

\section{Model Struktur Elemen dan Strategi Pengembangan BMT Maslahah}

Melalui teknik ISM, model mental yang tidak jelas ditransformasikan menjadi model sistem yang tampak (visible). Dalam hal ini struktur elemen-elemen dalam pengembangan BMT Maslahah dimodelkan sesuai dengan kebutuhan yang diperlukan dalam pengembangan BMT Maslahah. Berkembangnya BMT Maslahah dapat diindikasikan pada jumlah konsumen yang semakin meningkat dan mutu layanan yang semakin tinggi sebagai konsekuensi kesehatan organisasi. Keduanya memberikan pengaruh baik langsung maupun tidak langsung dalam mempengaruhi perilaku konsumen. Berdasarkan kajian dan diskusi dengan pakar yang merupakan praktisi BMT dan akademisi dapat disimpulkan bahwa terdapat dua elemen penting yang terkait dengan pengembangan BMT Maslahah. Kedua elemen tersebut adalah elemen dalam bentuk faktor pengambilan keputusan penggunaan produk \& loyalitas BMT dan elemen penyebab masalah dalam pengembangan kesehatan/kinerja organisasi BMT.

[Table 1 about here.]

\section{Model Struktural Elemen Pengembangan BMT Maslahah}

Pengambilan keputusan yang dimaksud sebagaimana diuraikan sebelumnya adalah faktor-faktor yang menjadi subelemen proses pengambilan keputusan dalam penggunaan produk BMT Maslahah oleh konsumen. Berdasarkan kajian kepustakaan dan hasil wawancara dengan para informan dapat diuraikan sebagaimana telah disampaikan sebelumnya bahwa elemen dari pengambilan keputusan adalah sebagaimana ditunjukkan pada tabel berikut:

[Table 2 about here.]

Selanjutnya berdasarkan pada aktivitas penilaian para narasumber dan ahli terkait dengan elemen pengambilan keputusan tersebut diperoleh hasil penilaian yang mendasarkan pada konteks keterpengaruhan dan hubungan antar subelemen. Selanjutnya, dari hasil penilaian disusun dalam bentuk Structural Similarity Index (SSIM) awal. SSIM awal disusun berdasarkan hubungan dan keterkaitan faktor-faktor yang merupakan sub-elemen dari pengambilan keputusan konsumen.

\section{[Figure 1 about here.]}

Berdasarkan Gambar 1 dapat dijelaskan bahwa sub-elemen kepercayaan yang utuh pada SDM BMT Maslahah memegang kunci yang mampu menggerakkan dan mempengaruhi subelemen lainnya dalam hal ini daya tarik terhadap manfaat dan sub-elemen lainnya seperti kepuasan pelayanan dan kesadaran penggunaan produk syariah. Artinya dalam proses pengambilan keputusan penggunaan produk BMT Maslahah kepercayaan pada SDM mampu menggerakkan dan mempengaruhi 
sub-elemen lainnya untuk menjadikan proses pengambilan keputusan menggunakan produk BMT Maslahah.

Dalam hal ini kesadaran pada prinsip syariah adalah kelompok sub-elemen kategori menengah dalam mempengaruhi dan menggerakkan proses pengambilan keputusan penggunaan produk BMT Maslahah. Adapun keunggulan dari pesaing dan juga sub-elemen biaya pindah adalah faktor yang memiliki daya gerak dan keterpengaruhan atau ketergantungan yang rendah dibandingkan dari elemen lainnya dalam mempengaruhi pengambilan keputusan penggunaan produk BMT Maslahah. Sedangkan dari sisi model Struktural Dinamika Masalah Pengembangan, dinamika masalah yang dimaksud sebagaimana diuraikan sebelumnya adalah aspekaspek atau faktor-faktor yang menjadi sub-elemen pada proses penyehatan atau kinerja BMT Maslahah. Berdasarkan kajian kepustakaan dan hasil wawancara dengan para informan dapat diuraikan sebagaimana telah disampaikan sebelumnya dan masalah dalam kesehatan organisasi BMT Maslahah dapat ditunjukkan pada tabel berikut:

[Table 3 about here.]

Selanjutnya berdasarkan pada aktivitas penilaian para narasumber dan ahli terkait dengan elemen elemen kesehatan/kinerja organisasi tersebut diperoleh hasil penilaian yang mendasarkan pada konteks keterpengaruhan dan hubungan antar sub-elemen. Selanjutnya hasil penilaian disusun dalam bentuk Structural Similarity Index (SSIM) awal. SSIM awal disusun berdasarkan hubungan dan keterkaitan faktorfaktor yang merupakan sub-elemen dari kesehatan/kinerja organisasi. Selanjutnya SSIM awal tersebut yang merupakan notasi huruf tersebut dikonversi ke angka biner sehingga menjadi Reachability Matrix (RM). Kemudian, mempertimbangkan daya gerak dan independensinya maka dari hasil matriks RM yang sudah terevisi tersebut selanjutnya dibuat model struktural Dinamika Masalah Kesehatan Organsasi dalam bentuk grafik ditunjukkan pada diagram sebagai berikut:

[Figure 2 about here.]

Berdasarkan pada Gambar 2 tersebut dapat diketahui bahwa Mutu Kepemimpinan (E6) memiliki Tingkat Pengendalian (Driver Power) serta Tingkat Kebebasan (Independence) paling tinggi, sedangkan Praktik Manajemen Dana Pihak ketiga (E5) merupakan sub-elemen yang yang memiliki Driver Power paling rendah. Hal ini menunjukkan bahwa E5 merupakan sub-elemen yang mampu dipengaruhi namun tidak dapat mempengaruhi, begitu pula sebaliknya, E6 merupakan sub-elemen yang sulit untuk dipengaruhi. Dalam hal ini, E6 merupakan sub-elemen yang memiliki pengaruh sangat tinggi dalam menyelesaikan masalah pengembangan kesehatan/kinerja organisasi BMT. Dari hasil permodelan menggunakan Interpretative Structural Modelling (ISM) dibuat gambar diagramnya ditunjukkan pada gambar sebagai berikut:
[Figure 3 about here.]

Dari Gambar 3 diatas dapat diketahui bahwa sub-elemen yang memiliki kemampuan sangat tinggi dalam mempengaruhi masaah-masalah kesehatan organisasi adalah Rujukan mutu kepemimpinan, sehingga untuk mengembangkan usahanya, BMT harus memiliki penguatan mutu kepemimpinan yang dilakukan kepada lembaga. Berdasarkan bagan tersebut dapat dijelaskan bahwa sub-elemen mutu Kepemimpinan BMT Maslahah memegang kunci yang mampu menggerakkan dan mempengaruhi sub-elemen lainnya dalam hal ini Pengendalian Sistem pengendalian SOP dan Kegiatan dan sub-elemen lainnya seperti praktik manajemen Resiko. Artinya dalam proses penyelesaian masalah untuk menyehatkan organisasi maka model kepemimpinan BMT Maslahah harus mampu menggerakkan dan mempengaruhi sub-sub elemen lainnya.

Dalam hal ini merujuk pada Gambar 3 dapat dijelaskan Kemampuan beradaptasi, mutu pelayanan pelanggan internal, kompetensi dan kapabilitas SDM, dan mutu pelyanan pelanggan eksternal adalah kelompok sub-elemen kategori menengah dalam mempengaruhi dan menggerakkan proses penyehatan/kinerja organisasi BMT Maslahah. Adapun kejelasan visi dan juga sub-elemen manajemen dan pihak ketiga adalah faktor yang memiliki daya gerak dan keterpengaruhan atau ketergantungan yang rendah dibandingkan dari elemen lainnya dalam mempengaruhi proses penyelsaian masalah utamanya terkit penyehatan dan kinerja organisasi BMT Maslahah.

Upaya untuk meningkatkan dan mengembangkan BMT Maslahah sebagai lembaga keuangan mikro yang melayani masyarakat adalah sebuah keharusan. Keharusan tersebut disebakan karena jumlah peran BMT Maslahah secara faktual dan aktual benar-benar berkontribusi terhadap perekonomian umat. Prinsip-prinsip syariah yang tercermin dalam bentuk penerimaan oleh masyarakat bahwa BMT Maslahah memiliki praktik keadilan, kemanfaatan, dan kemudahan serta berpihak pada masyarakat kecil terus ditumbuhkan.

Pengembangan organisasi BMT Maslahah sudah semestinya didasarkan pada upaya-upaya untuk meningkatkan jumlah konsumen yang tercermin pada semakin meningkatnya perilaku positif konsumen dalam bentuk loyalitas pada produk dan upaya-upaya untuk meningkatkan kesehatan dan kinerja organisasi. Kedua hal tersebut menjadi faktor-faktor penting dalam memerankan layanan lembaga keuangan berbasis syariah yang mudah diakses oleh masyarakat sekaligus memberikan peran pemberdayaan umat. Selain itu upayaupaya untuk meningkatkan pengembangan organisasi harus benar-benar berdasarkan pada masalah-masalah aktual yang dihadapi oleh BMT Maslahah sekaligus melihat kondisi tantangan lingkungan internal maupun eksternal.

Berdasarkan strukturisasi faktor atau sub-elemen pada bagaimana proses pengambilan keputusan dalam penggunaan produk BMT Maslahah dan dinamika masalah dalam kesehatan organisasi dan kinerja organisasi maka dapat disusun alternatif skenario dan strategi pengembangan organisasi BMT 
Maslahah. Pada penguatan loyaliltas penggunaan produk oleh konsumen dan dalam rangka pengembangan daya terima produk BMT Maslahah oleh calon konsumen maka prioritas strategi yang dapat dikembangkan adalah:

Pertama, meningkatkan kepercayaan pada SDM melalui peguatan kapasitas dan kapabilitas SDM BMT Maslahah. Penguatan kapasitas dan kapabilitas SDM BMT Maslahah dapat dilakukan dengan memperbaiki sistem perencanaan, rekruitmen, seleksi dan penempatan SDM secara profesional berdasarkan kebutuhan aktual.

Kedua: meningkatkan realisasi daya tarik imbalan/manfaat keuntungan yang diberikan BMT Maslahah. Realisasinya dalam bentuk penerjemahan yang seksama dan tepat pada implementasi pelayanan yang didasarkan pada prinsip syarian dan kepuasan pelayanan menggunakan pendekatan berorientasi kepuasan pelanggan berbasis Mutu Manajemen Terpadu (MMT).

Ketiga: memperkuat hubungan dengan tokoh berpengaruh masyarakat yang menjadi rujukan masyarakat dan diferensiasi secara jelas penguatan daya tarik produk yang ditawarkan. Sosialisasi dan silaturrahim BMT Maslahah sebagai salah satu media fasilitasi dan pemberdayaan umat Islam harus dilakukan secara kontinyu dilakukan kepada para tokoh pesantren dan kelompok rujukan lainnya.

Sedangkan upaya-upaya untuk menyelesaikan masalah penguatan kesehatan/kinerja organisasi BMTM maka strategi yang dapat dikembangkan adalah:

Pertama: meningkatkan Mutu kepemimpinan di semua level manajemen dan struktur organisasi BMT Maslahah. Penguatan mutu kepemimpinan diterjemahkan dalam kapabilitas dan kompetensi pencapaian visi yang jelas, kepemimpian yang melibatkan dan memberdayakan anggota organisasi, kepekaan terhadap dinamika lingkungan yang menjadi tantangan pengembangan BMT Maslahah, serta kapabilitas dan kompetensi dalam menjalankan manajemen organisasi.

Kedua: memperkuat Implementasi Sistem Pengendalian dan SOP kegiatan dan praktik manajamen resiko pembiayaan. Sebagai organisasi penyelenggara jasa layanan keuangan maka penguatan implementasi harus dititik beratkan pada upaya memperjelas proses bisnis BMT Maslahah dan meterjemahkannya dalam bentuk standarisasi semua proses dan kegiatan dalam bentuk SOP khususnya yang terkait dengan inti bisnis BMT Maslahah.

Ketiga: meningkatkan Kemampuan Beradaptasi dan Melihat Peluang, mutu pelayanan pada pelanggan internal dan eksternal, serta penataan profesionalitas SDM. Peningkatan mutu pelayanan harus diorientasikan baik pelanggan eksternal, maupaun para anggota organisasi dalam hal ini semua SDM organisasi sebagai pelanggan eksternal. Kepuasan akan memberikan makna positif pada kesehatan organisasi karena menjadi motif pendorong kinerja.
Pengembangan strategi sebagaimana disampaikan sebelumnya dapat dimaknai dalam perspektif prioritas waktu atau kemampuan sumberdaya yang dimiliki oleh lembaga BMT Maslahah. Dalam konteks ini apabila terdapat keterbatasan sumberdaya, maka prioritas-prioritas yang disampaikan sebagai stratgei pengembangan BMT Maslahah dilakukan berdasarkan penetapan waktu. Misalnya prioritas pertama adalah strategi yang akan dilaksanakan pada tahun pertama dan melakukan evaluasi pada ujung tahun untuk merekomendasikan kegiatan pada tahun kedua bersamaan atau simultan dengan pelaksanaan strategi prioritas kedua.

Selain itu prioritas-prioritas tersebut haruslah dielaborasi dan dikoordinasikan baik pada penguatan elemen pengambilan keputusan penggunaan produk maupun kesehatan/kinerja organisasi. Sinergi harus dilakukan untuk memudahkan pengerahan sumberdaya yang terbatas pada organisasi BMT Maslahah untuk memaksimalkan strategi pengembangan yang dipiih sebagai prioritas. Sinergi itu juga harus dikelola dalam suatu manajemen yang sederhana, terukur, terencana, dapat direalisasikan, dan berdasarkan penetapan waktu capaian yang jelas. Komitmen seluruh pihak atau para pemangku kepentingan BMT Maslahah menjadi faktor pengungkit yang besar bagi keberhasilan implementasi strategi tersebut.

\section{KESIMPULAN}

Perilaku konsumen pada BMT Maslahah Pasuruan meliputi pemahaman yang tepat terhadap produk, sikap positif pada produk, dan kesadaran bertindak dalam bentuk pemilihan dan penggunaan produk BMTM. Pemahaman dan sikap positif terhadap produk BMTM didasarkan pada motif kebutuhan hidup sehari-hari dan pengembangan usaha, disamping faktor-faktor penerimaan nilai syariah dalam bentuk keberkahan pada saat menggunakan produk BMTM. Pengambilan keputusan dilakukan setelah evaluasi dari pencarian informasi lanjutan dengan penggunaan terbesar adalah tabungan atau simpanan, pinjaman atau bentuk keduanya tabungan dan simpanan sedangkan loyalitas terbentuk setelah penggunaan karena konfirmasi positif dalam bentuk kepuasan dengan realisasi layanan yang diawarkan.

Upaya BMT dalam membangun loyalitas konsumen pada BMT Maslahah Sidogiri Pasuruan dengan mendekatkan layanan kepada masyarakat diantaranya dengan meningkatkan kepercayaan kepada SDM BMT, meningkatkan realisasi daya tarik imbalan, dan memperkuat hubungan dengan tokoh berpengaruh dimasyarakat. Sedangkan untuk meningkatkan kinerja organisasi hal-hal yang dapat dilakukan adalah Meningkatkan Mutu kepemimpinan, Memperkuat Implementasi Sistem Pengendalian dan SOP kegiatan dan praktik manajamen resiko pembiayaan, dan meningkatkan kemampuan beradaptasi serta melihat Peluang. 


\section{REFERENCES}

Ali, H. (2002). Perilaku Konsumen (Jakarta: Refika Aditama).

Ekaningsih, F. (2016). Lembaga Keuangan Bank dan Non-Bank, Kopertais wilyah IV Surabaya.

Kotler, P. (2012). Building Customer Loyalty Trough Quality, Upper Saddle River: Person Education. 2012. .

Schiffman, L. G. and Kanuk, L. (2012). Consumer Behavior. International Edition Prentice Hall.

Conflict of Interest Statement: The author declare that the research was conducted in the absence of any commercial or financial relationships that could be construed as a potential conflict of interest.

Copyright (C) 2020 Parmujianto. This is an open-access article distributed under the terms of the Creative Commons Attribution License (CC BY). The use, distribution or reproduction in other forums is permitted, provided the original author(s) and the copyright owner(s) are credited and that the original publication in this journal is cited, in accordance with accepted academic practice. No use, distribution or reproduction is permitted which does not comply with these terms. 


\section{LIST OF TABLES}

1 Elemen dan Sub-elemen terkait Pengembangan BMT . . . . . . . . . . . . . . . . . . . . . . 32

2 Sub-elemen Pengambilan Keputusan Penggunaan Produk Dan Loyalitas . . . . . . . . . . . . . . . . . . . . 33

3 Sub-elemen Dinamika Masalah Kesehatan Organisasi 
TABLE 1 | Elemen dan Sub-elemen terkait Pengembangan BMT

\begin{tabular}{|c|c|c|c|}
\hline \multicolumn{2}{|r|}{$\begin{array}{l}\text { Elemen dalam bentuk faktor pengambilan keputusan } \\
\text { penggunaan produk dan loyalitas BMT }\end{array}$} & \multicolumn{2}{|c|}{$\begin{array}{l}\text { Elemen penyebab masalah dalam pengembangan } \\
\text { kesehatan/kinerja organisasi BMT }\end{array}$} \\
\hline No. & Sub-elemen & No. & Sub-elemen \\
\hline 1 & Daya Tarik Produk yang Ditawarkan & 1 & Mutu Pelayanan Pada Pelanggan Eksternal \\
\hline 2 & Daya Tarik Imbalan/Manfaat Keuntungan yang Diberikan & 2 & Kompetensi dan Kapabilitas SDM Organisasi \\
\hline 3 & Kepuasan pada Pelayanan & 3 & Mutu Pelayanan dan Pelanggan Internal \\
\hline 4 & Kesadaran pada Prinsip Syariah & 4 & Praktik Manajemen Resiko Pembiayaan \\
\hline 5 & Rujukan Tokoh Berpengaruh & 5 & Praktik Manajemen Dana Pihak ketiga \\
\hline 6 & Keunggulan dari Pesaing & 6 & Mutu Kepemimpinan \\
\hline 7 & Kepercayaan pada SDM & 7 & Kejelasan Visi dan Orientasi Organisasi \\
\hline \multirow[t]{2}{*}{8} & Biaya Pindah pada Lembaga Keuangan Lainnya & 8 & Kejelasan Sistem Pengendalian dan SOP Kegiatan \\
\hline & & 9 & Kemampuan Beradaptasi dan Melihat Peluang \\
\hline
\end{tabular}


TABLE 2 | Sub-elemen Pengambilan Keputusan Penggunaan Produk Dan Loyalitas

\section{Kode Sub-elemen}

E1 Daya Tarik Produk yang Ditawarkan

E2 Daya Tarik Imbalan/Manfaat Keuntungan yang Diberikan

E3 Kepuasan pada Pelayanan

E4 Kesadaran pada Prinsip Syariah

E5 Rujukan Tokoh Berpengaruh

E6 Keunggulan dari Pesaing

E7 Kepercayaan pada SDM

E8 Biaya Pindah pada Lembaga Keuangan Lainnya 
TABLE 3 | Sub-elemen Dinamika Masalah Kesehatan Organisasi

\begin{tabular}{ll} 
Kode & Sub-elemen \\
E1 & Mutu Pelayanan Pada Pelanggan Eksternal \\
E2 & Kompetensi dan Kapabilitas SDM Organisasi \\
E3 & Mutu Pelayanan dan Pelanggan Internal \\
E4 & Praktik Manajemen Resiko Pembiayaan \\
E5 & Praktik Manajemen Dana Pihak ketiga \\
E6 & Mutu Kepemimpinan \\
E7 & Kejelasan Visi dan Orientasi Organisasi \\
E8 & Kejelasan Sistem Pengendalian dan SOP Kegiatan \\
E9 & Kemampuan Beradaptasi dan Melihat Peluang \\
\hline
\end{tabular}




\section{LIST OF FIGURES}

1 Matriks DP-D pengambilan keputusan penggunaan Produk . . . . . . . . . . . . . . . . . . 36

2 Matriks DP-D pengambilan keputusan penggunaan Produk. . . . . . . . . . . . . . . . . . . . . 37

3 Model Struktural Dinamika Masalah Kesehatan Organisasi . . . . . . . . . . . . . . . . . . . . . . . . 38 


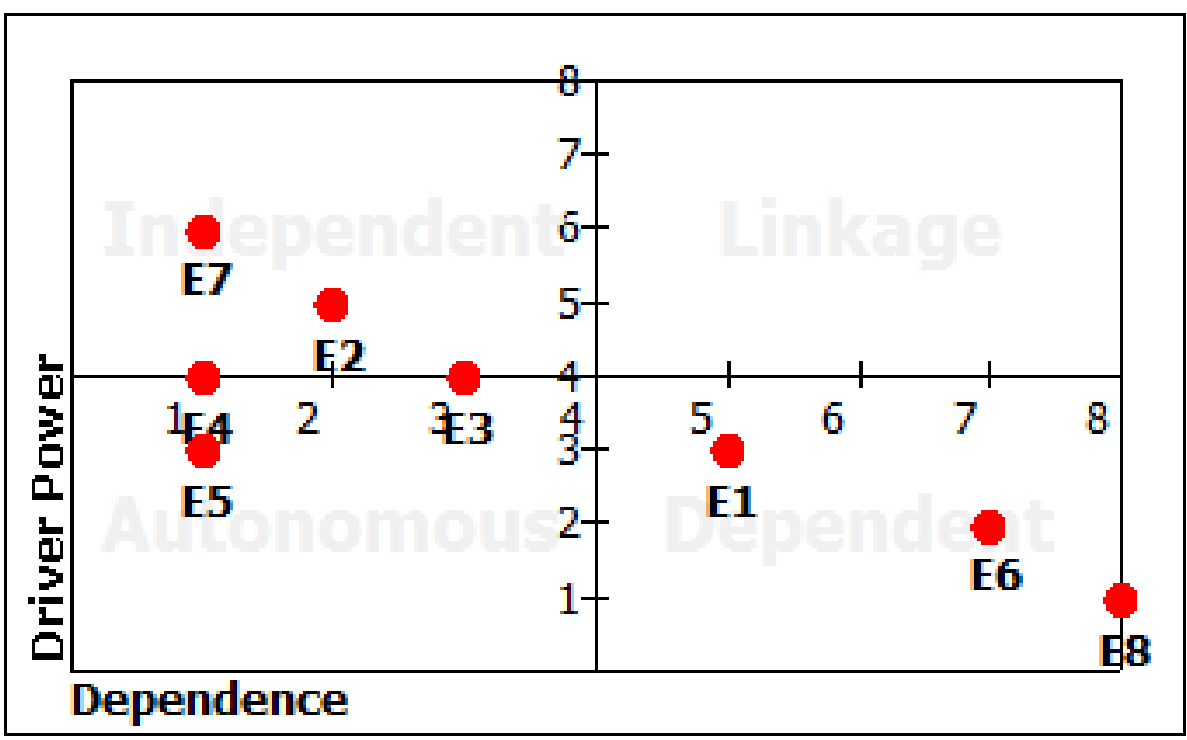

FIGURE 1 | Matriks DP-D pengambilan keputusan penggunaan Produk 


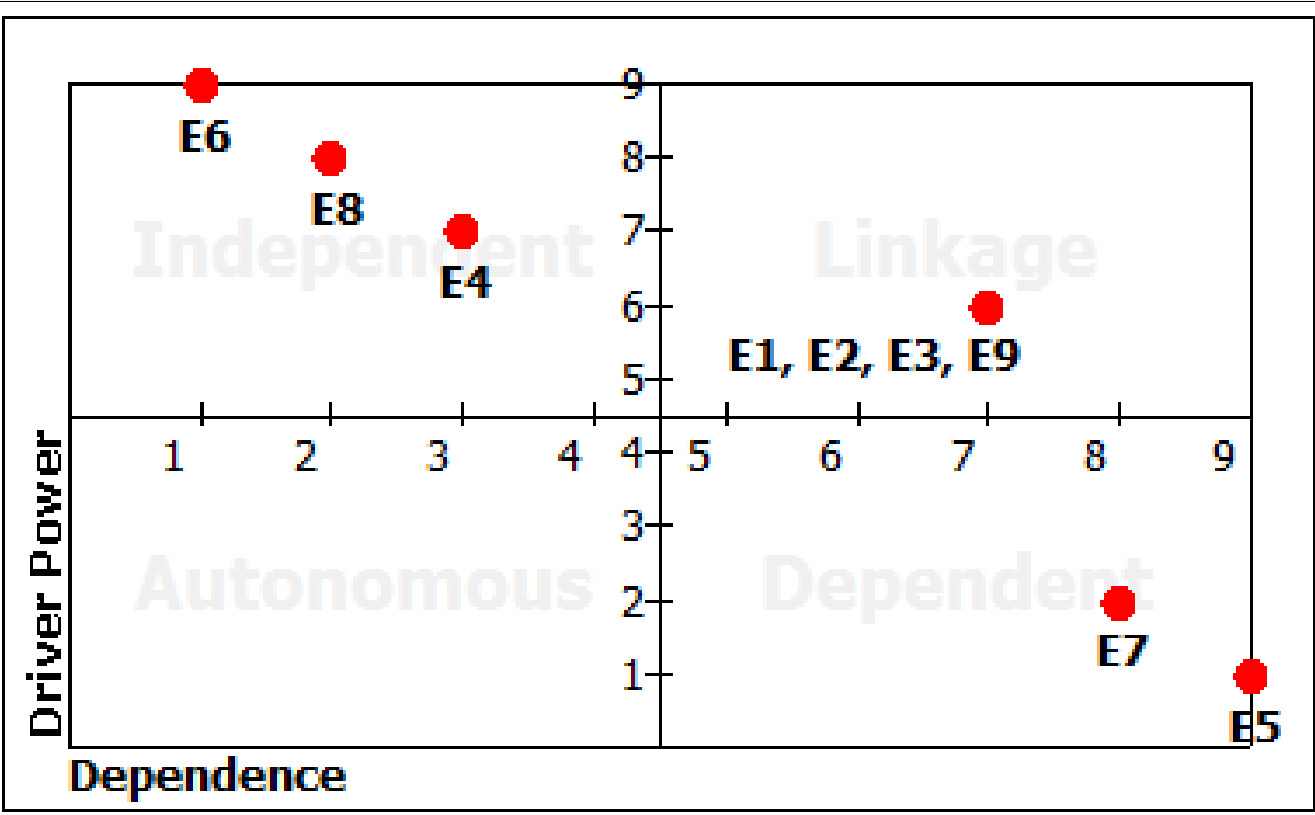

FIGURE 2 | Matriks DP-D pengambilan keputusan penggunaan Produk. 


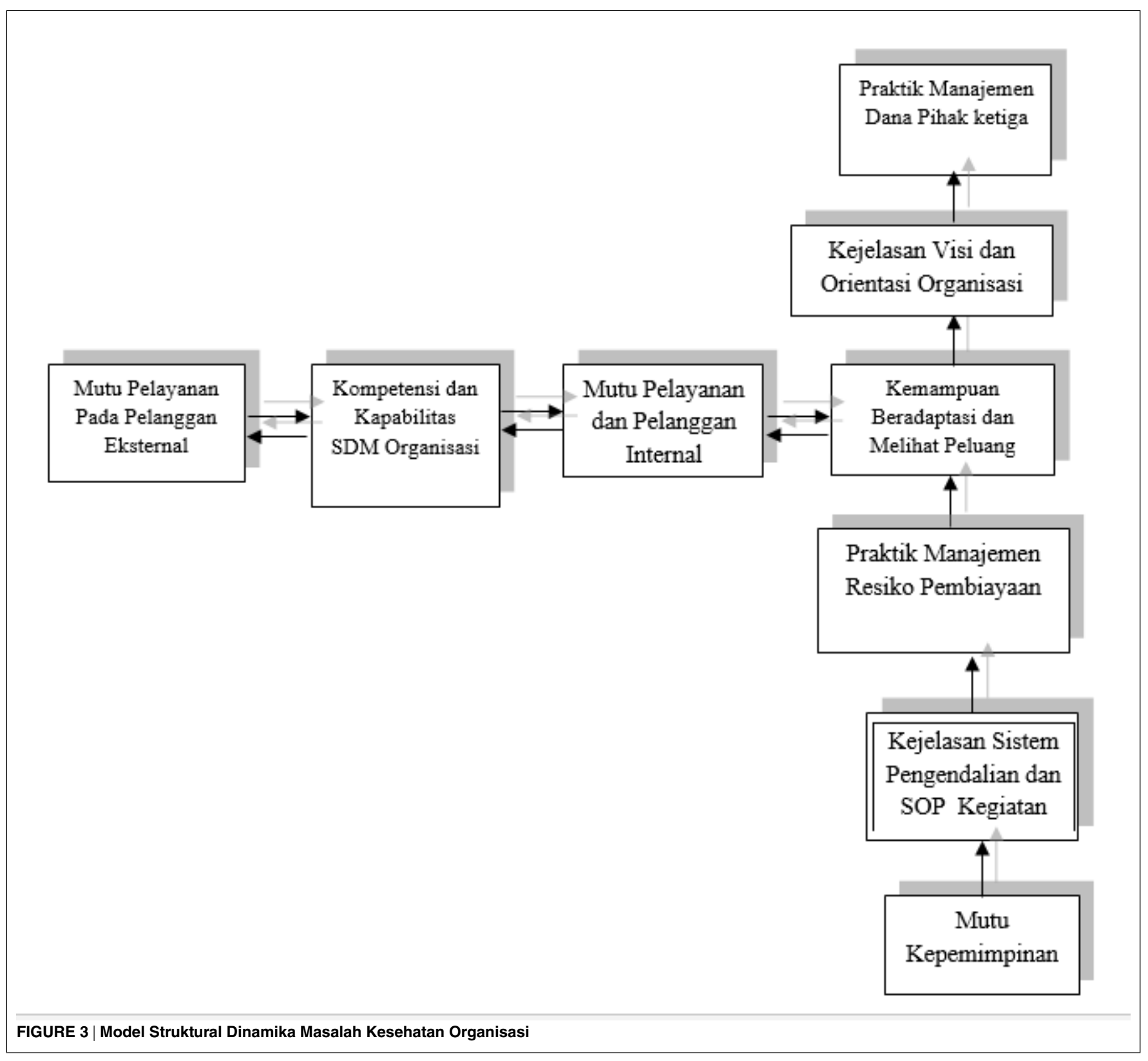

